\section{A highly informative CACA repeat polymorphism upstream of the human dystrophin gene (DMD)}

J.P.Hugnot, D.Récan, M.Jeanpierre, J.C.Kaplan and A.Tolun * INSERM U129, ICGM, CHU Cochin, 75014 Paris, France

Source/Description: The polymorphic $(\mathrm{CA})_{14}$ repeat is located approximately $1.5 \mathrm{~kb}$ upstream of the first brain-type exon of the human dystrophin gene at $\operatorname{Xp} 21(1,2)$.

\section{CA Primer: 5'-TAGCTAAAATGTATGAGTA-3' \\ GT Primer: 5'-AATAGTGTTTTCCTAAGGG-3'}

Frequency: Determined from 68 chromosomes of unrelated individuals. PIC: 0.78 .

$\begin{array}{llll}\text { Allele (bp) } & \text { Frequency } & \text { Allele (bp) } & \text { Frequency } \\ \text { AG9: (88) } & 0.34 & \text { AG5: (100) } & 0.25 \\ \text { AG8: (94) } & 0.01 & \text { AG4: (102) } & 0.03 \\ \text { AG7: (96) } & 0.01 & \text { AG3: (104) } & 0.11 \\ \text { AG6: (98) } & 0.10 & \text { AG2: (106) } & 0.14 \\ & & \text { AG1: (108) } & 0.01\end{array}$

Mendelian Inheritance: Co-dominant segregation was observed in seven informative families.

Other Comments: The PCR reaction $(25 \mu \mathrm{l})$ contains $200 \mathrm{ng}$ DNA, $1 \mu \mathrm{M}$ of each primer, 3 units of Taq polymerase (Cetus), $0.2 \mathrm{mM}$ each dNTP, $1.5 \mathrm{mM} \mathrm{MgCl} 2,50 \mathrm{mM} \mathrm{KCl}$ and $10 \mathrm{mM}$ Tris- $\mathrm{HCl} \mathrm{pH}$ 8.3. Amplification conditions: $94^{\circ} \mathrm{C}(7 \mathrm{~min})$, followed by 25 cycles of $94^{\circ} \mathrm{C}(1 \mathrm{~min}), 55^{\circ} \mathrm{C}(2 \mathrm{~min}), 72^{\circ} \mathrm{C}$ ( $3 \mathrm{~min}$ ). Alleles may be observed either on a $12 \%$ polyacrylamide gel or, for some of them, on a $3 \%$ NuSieve $\left(\right.$ FMC $\left.^{\circledR}\right)+1 \%$ agarose gel. The polymorphism is useful in determining the inheritance of DMD in individuals at risk (see Figure).

Acknowledgements: Supported by grants from the Association Française contre les Myopathies (AFM).

References: 1) Nudel,U., et al. (1989) Nature 337, 76-78. 2) Boyce,F.M. et al. (1991) Proc. Natl. Acad. Sci. USA 88, 1276-1280.

Note Added in Proof: This CA repeat corresponds to the 5'-DYSII marker that was published by Feener et al. (Am. J. Hum. Genet. (1991), 48, 621-627) while the present report was submitted.

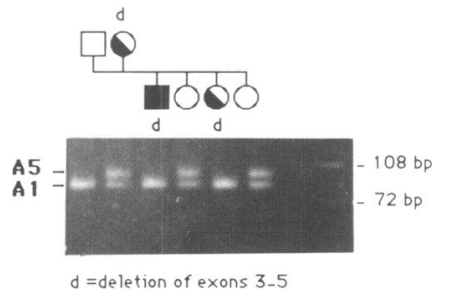

*Permanent address: Department of Biology, Bogazici University, Bebek 80815 , Istanbul, Turkey

\section{Aatll polymorphism in von Willebrand factor gene at codon 471}

\author{
D.J.Bowen, C.E.Webb, I.R.Peake ${ }^{1}$ and A.L.Bloom \\ Department of Haematology, University College of \\ Medicine, Heath Park, Cardiff CF4 4XN and ${ }^{1}$ Royal \\ Hallamshire Hospital, Glossop Road, Sheffield S10 2JF, \\ UK
}

Source/Description: Published nucleotide sequences of the human von Willebrand factor gene show a nucleotide difference at the first base of codon 471 in comparison with other published sequences $(1,2,3)$. A potential Aat II recognition site is present when the base is G (GACGTC) but absent when it is A.

Polymorphism: Detected using the PCR and subsequent digestion of the product with AatII. PCR conditions: $50 \mathrm{mM} \mathrm{KCl,} 10 \mathrm{mM}$ tris- $\mathrm{HCl} \mathrm{pH} 8.5,1.5 \mathrm{mM} \mathrm{MgCl}_{2}, 0.01 \%$ gelatin, $100 \mu \mathrm{M}$ of each dNTP, $250 \mathrm{ng}$ of genomic DNA, $1 \mathrm{U}$ of T.aq. DNA polymerase and $0.5 \mu \mathrm{M}$ of each primer $\mathrm{A}$ and primer $\mathrm{B}$ in a total volume of $100 \mu \mathrm{l}$. The following PCR regime: $94^{\circ} \mathrm{C}$ for $3 \mathrm{~min}$; $55^{\circ} \mathrm{C}$ for addition of enzyme; 30 cycles of: $72^{\circ} \mathrm{C}$ for $1 \mathrm{~min} ; 94^{\circ} \mathrm{C}$ for $30 \mathrm{~s}$ and $55^{\circ} \mathrm{C}$ for $30 \mathrm{~s} ; 72^{\circ} \mathrm{C}$ for $10 \mathrm{~min}$. PCR product $(5$ $\mu l)$ was diluted to $20 \mu \mathrm{l}$ with $15 \mu \mathrm{l}$ of $1 \times$ AatII buffer $(50 \mathrm{mM}$ $\mathrm{KCl}, 10 \mathrm{mM}$ tris- $\mathrm{HCl} \mathrm{pH} 7.5,10 \mathrm{mM} \mathrm{MgCl} 2$ and $1 \mathrm{mM}$ dithiothreitol) containing $2 \mathrm{U}$ of AatII. The digest was incubated at $37^{\circ} \mathrm{C}$ for $3 \mathrm{~h}$ and then analysed by PAGE using a $6 \%$ gel. Aat $\Pi$ $(-/-)$ individuals show one band at $229 \mathrm{bp}$, Aat II $(+/+)$ individuals show two bands at $154 \mathrm{bp}$ and $75 \mathrm{bp}$, and Aat II (+/-) individuals show all three bands.

\section{Primers:}

Primer A: 5' GTGCAGCAAAGTCACCCTGTCTT3', Primer B: 5' TGCTAAGGGATGGGCTGTGCCA3',

Primers A and B correspond to nucleotides 9/60-82 and 9/267-288 respectively in Mancuso et al. (1).

Chromosomal Location: 12pter-p12; vWF gene; codon 471.

Mendelian Inheritance: Codominant inheritance observed in one family.

Frequency: Estimated from 40 unrelated caucasian individuals (80 chromosomes 12 ).

$(+)=0.45(-)=0.55$ heterozygosity rate $=0.49$

References: 1)Mancuso,D.J. et al. (1989) J. Biol. Chem. 264, 19514-19527. 2)Bonthron et al. (1986) Nucl. Acids Res. 14, 7125-7127. 3)Veweij et al. (1986) Embo J. 5, 1839-1847.

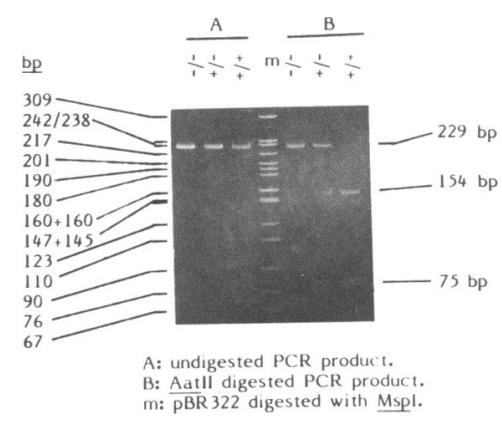

